\title{
Bireysel Şiddet Açısından Spor Medyasının Etkileri
}

\author{
The Effects of Sports Media in Terms of Individual Violence
}

\author{
M. Yalçın TAŞMEKTEPLIGGIL* \\ Veysel KÜÇÜK ${ }^{* *}$ \\ Seydi KARAKUŞ ${ }^{* * *}$ \\ Arslan KALKAVAN ${ }^{* * *}$
}

\section{Öz}

$\mathrm{Bu}$ çalışma, yazılı ve görsel medyada yer alan haber ve programların bireysel şiddet açısından etkilerini belirlemek, kişilerin saldırganlık veya fair-play’e yönelmelerinde etkili olabileceği düşünülen haber ve programların analizini yapmak ve bu konuda çözüm önerileri sunmak amacını taşımaktadır.

Çalışmanın örneklemini, Türkiye’nin 6 coğrafi bölgesinde yer alan 8 İl’deki 1170 gönüllü kişi (erkek: \% 58,7; kadın \%41,3) oluşturmaktadır. Araştırmada bilgi toplamak amacıyla 14 sorudan oluşan bir anket uygulanmıştır. Araştırma kapsamında elde edilen verilerin istatistiksel çözümlemesinde frekans, yüzde ve Ki-Kare dağılım ve analizlerinden yararlanılmış, böylece spor medyasının bireysel şiddet açısından etkileri örneklemin; yaş, cinsiyet, meslek ve eğitim özellikleri yönünden ne derece farklılaştığ değerlendirilmiştir.

Çalışma sonuçlarına göre "medyadaki spor programlarını takip etme" kadınlara göre erkeklerde, kamu ve serbest çalışana göre de öğrencilerde anlamlı şekilde yüksek bulunmuştur. Medya yayınlarını takip yaş yükseldikçe düşmektedir. Eğitim kademelerinde ise en düşük izlenme oranı ilköğretim kademesi mezunlarında görülmektedir. Diğer yandan, medyada yer alan spor programlarının eğitim açısından yeterliliğinde; yaş, cinsiyet ve meslek özellikleri açısından herhangi bir farklılı̆̆a rastlanmazken, eğitim seviyesinde lise kademesi lehinde önemli bir değişim belirlenmiştir. TV spor programlarının şiddeti artırma yönündeki etkisine katılımda ise, yaş ve meslek grupları açısından anlamlı bir farklılık gözlenmiştir. 13-30 yaş arası gruplar 31-50 yaş gruplarına göre, TV programlarının şiddeti artırma yönündeki değerlendirmesine daha çok katılmaktadırlar. Bu görüş öğrencilerde de yüksek orandadır. Spor medyası yazarları hakkındaki düşünceler katılımcıların yaş ve eğitim değişkenlerinde anlamlı bir değişim göstermiştir. Burada daha çok yazarların "yanlı" olmaları hususunun 13-30 yaş grupları ve liseüniversite mezunlarında sorun olarak görüldüğü anlaşılmaktadır.

\footnotetext{
Prof. Dr., OnDokuz Mayıs Üniversitesi Spor Bilimleri Fakültesi, myalcint@omu.edu.tr

** Doç. Dr., Marmara Üniversitesi Öğretim Üyesi, Spor Bilimleri Fakültesi, veysel.kucuk@marmara.edu.tr

*** Dumlupınar Üniversitesi, Beden Eğitimi Spor Yüksekokulu, seydi.karakus@dpu.edu.tr

**** Recep Tayyip Erdoğan Üniversitesi, Beden Eğitimi Spor Yüksekokulu, arslan.kalkavan@erdogan.edu.tr
} 
Çalışmanın bir başka sonucuna göre, spor medyasının bireyler üzerindeki etkisi, sadece yaş ve eğitim durumu değişkenlerinde anlamlıdır. Spor medyasının fanatizmi tetiklenmesi konusunda tam bir görüş birliği olduğu söylenebilir.

Diğer yandan bütün katılımcılar, medya spor yayın ve haberlerinin spor eğitimini işlevseltirmek yönünden yetersizliğini vurgulamakta, futbolla ilgili yayınların yerine sağlık ve spor bilgisini arttırıcı, hatta spora katılımı özendirici programlara öncelikle yer verilmesi gerektiği görüşünü dile getirmektedir. Sonuç olarak, medya yayın ve haberleri okuyucu ve izleyici dikkatini çekmek niyetiyle belirli kalıplar içinde sunulurken, daha titiz davranılmalı, gerek psikolojik gerekse toplumsal algının bireyleri şiddet ve saldırgan davranışlara yönlendirebileceği dikkate alınmalıdır.

Anahtar Kelimeler: Medya, Şiddet, Televizyon, Gazete

\section{Abstract}

The purpose of this study is to find out the effects of news and programs in printed and visual media in terms of individual violence, analyze the news and programs which are thought to have an effect on individual's inclining to aggression or fair-play and present suggestions on this issue.

The sample of the study consists of 1170 volunteers (men: 58.7\%; women: 41.3\%) from 8 cities in 6 different geographical regions in Turkey. A questionnaire with 14 questions was used to collect data in the study. Frequency, percentage and Chi-square distribution and analyses were used for the statistical analysis of the data in order to assess the effects of sports media in terms of individual violence and to what extent the age, gender, occupation and educational features of the sample affects these effects. According to the results of the study, the ratio of 'following sports programs in the media' was found to be significantly higher in men compared to women and in students compared to public officers and self-employed. The ratio of 'following media' was found to decrease as the age increases. In terms of educational status, primary education graduates were found to have the lowest rate of viewing. On the other hand, in terms of the educational sufficiency of sports programs in media, no difference was found in age, gender and occupational features, while a significant difference was found in high school level. In terms of agreeing with the effect of TV sports programs towards increasing violence, a significant difference was found in terms of age and occupation groups. 15-30 age group was found to agree more that TV programs increased violence when compared with the 31-50 age group. The rate of this view was high in students.

Thoughts about sports media authors showed a significant difference in terms of the variables of participants' ages and educational status. It was found that the issue of authors' being "biased" was seen as a problem in 13-30 age group and high school and university graduates. Another result of the study was that the effect of sports media on individuals was effective only on the variables of age and educational status. It can be said that there is a complete consensus on the view that sports media triggers fanaticism.

On the other hand, all of the participants mentioned the insufficiency of media sports broadcasts and news in terms of making sports education functional and stated that instead of broadcasts about football, programs that increase health and sports knowledge and encourage participation in sports should be prioritized. As a conclusion, while media broadcasts and news are presented within specific patterns in order to attract the attention of readers and viewers, the media should be more careful and should take into consideration that psychological or social perceptions can lead individuals to violence and aggressive behaviors.

Keywords: Media, Violence, Television, Newspaper 


\section{GiRiş}

İletişim kavramı, bilgi akışını ifade eden geniş bir açılıma sahiptir. Bu yüzden iletişim, bir "yayımlama eylemi” olduğu kadar "alma ve tepki göstermeyi de kapsar. Günümüzde hızla gelişen ve yaygınlaşan bir iletişim çağı yaşanmakta, bu ise insanlar ve toplumlar arasındaki diyalogu daha güncel ve etkileyici kılmaktadır (Karaküçük ve Yenel, 1999). Bu nitelikteki haberleşmenin bazı tekniklerle, çok sayıda kişiyi etkileyecek biçime getirilmesine kitle haberleşmesi (mass communication), burada kullanılan araçlara da kitle haberleşme araçları (mass media) denilir (Döşyılmaz, 1998).

Yazılı ve görsel iletişim olarak kabul edilen kitle iletişi araçlarının en önemlileri televizyon ve gazetelerdir. Televizyon ve gazetelerin sporla ilgili yayınları kitleleri manipüle etmede kullanılan en önemli kısımlardır. Çünkü spor programları ve gazetelerin spor sayfaları izleyici ve okurların bakmayı ihmal etmedikleri bölümlerdir. Hatta birçok okurun gazeteyi spor sayfasından başlayarak okuduğu ve birçok kişinin de sadece spor haber ve programları izlediği söylenebilir. Öyleyse günümüzde haber almak veya izlemek bir alışkanlık halini almıştır (Öztürk ve Ark., 1996). Çok sayıda insanın gerek bilgi edinmek, gerekse boş vakitlerini değerlendirmek amacıyla kitle iletişim araçlarına yönelmeleri medyanın insanlar üzerinde etkili olmasına yol açmaktadır”

Kitle iletişim araçlarının fonksiyonları, genel olarak; haber ve bilgi sağlama, sosyalleştirme, motivasyon, tartışma ortamı hazırlama, eğitimin kültürünün gelişmesine katkı, eğlendirme ve bütünleştirme olarak sıralanabilir (Yetim, 2000).

Kitle iletişim araçlarının kaynak ve hedef kitle açısından işlevleri esas alındığında, medya amacına ulaşır ve görevini yapmış olur. Bütün bu değerlerin yanında, spor yazar ve programcıları spor alanlarındaki iş dünyasının ekonomik çıkarlarını, mesleki ve profesyonel normları ile spor kamusunun duygusal yatırımlarını uzlaştırma gibi bazı zorunluluklara da uymak durumundadırlar (Karaküçük ve Yenel, 1999).

Bilindiği gibi, sporun yarışmaya yatkın doğası, eski zamanlardan beri, insanlar arasında üstünlük mücadelelerine yol açmıştır. Bu mücadeleler çoğu kez insanlar ve toplumlar arasındaki ilişkileri düzenleyici ve geliştirici roller oynamışlarsa da bunların oran olarak az, sayı olarak ise hiç azımsanmayacak bir kısmı düşmanlıklara sebep olmuş ya da var olan düşmanlıkları körüklemiştir. Şüphesiz bu durum, bir kimseye veya bir şeye aşırı düşkünlük ve tutkuyla bağl1lık, taassup yahut bağnazlık (Bayhan, 2000) sözcüklerinde anlam bulan "fanatizm" kavramını ortaya çıkarmıştır. Özellikle futbol, birçok bakımdan gençlerin anlamlı, heyecanlı ve zevkli buldukları etkinlik türleri için son derece elverişli bir ortamdır.

Futbolda şiddet eğilimi 1950'li yılların sonlarına kadar gündemi çok meşgul etmezken 1960'lı yılların başından itibaren yeniden yükselişe geçmiş, hatta 1970-80'li yıllarda özellikle İngiltere’nin önemli sorunlarından birisi halini almıştır. 1980'li yıllardan itibaren de şiddet eğilimi bir hastalık gibi dünyanın birçok ülkesine yayılmıştır. Halen bu tür davranış ve eğilimler, futbolda karşımıza çıkan önemli sorunların başında olmaya ve gündemi meşgul etmeye devam etmektedir 
(Taşmektepligil ve ark, 2015). Bu çerçevede futbol fanatizmi, bir futbol maçı öncesinde, anında veya sonrasında kasıtlı olarak tasarlanmış gibi görünen ve şu ya da bu derece şiddet içerebilen olayları kapsamaktadır. Fanatizm olaylarında maça girerken dövüşme ve düzen bozucu davranış amacı taşımayan seyirciler bulunmakla birlikte, en ısrarlı bir şekilde saldırganlık ve şiddeti maça gitmenin ayrılmaz bir parçası olarak gören izleyiciler de vardır (İkizler, 1994).

Saldırganlık; duygu, niyet, amaç ve davranış öğeleri ile birlikte değerlendirilmesi gereken çok yönlü bir kavramdır. Bu manada, fazlasıyla gayri meşru yahut tasvip edilemez tutumlara karşılık düşer. Fakat ne var ki, şiddetin uygulayıcısı tarafından özellikle bu öğe kolaylıkla küçümsenir, hatta tümüyle göz ardı edilir (Acet, 2001). Oysa şiddet, kültürel değer ve normlardan oluşan devasa bir geri plandir.

Gerçekten bazı araştırmacılar eğitim ve öğrenimle bir hayat boyu geliştirilenin, kişiliğin cilası olduğunu ileri sürmüşlerdir. Doğrudan davranışı ve heyecanları düzenlemeye yönelik sistemli bir eğitim veya tedavi uygulanmadığı takdirde insanın anlık tepkilerinin hiç azımsanamayacak bir bölümünün ilk kazanılan bilgi, öğrenme, şartlanma; kısacası, daha önce anlatılan temel kalıplar doğrultusunda olduğu bilinir. Bu temel kalıpların davranış düzeyinde sağlığa zarar vermeyecek biçimde yeniden programlanması belki günün birinde hücre hafızası düzeyinde bir değişim sağlanmasını mümkün kılacaktır (Baltaş ve Baltaş, 1990).

Bununa birlikte çoğu kez içinde şiddet bulunduran futbol fanatikliği olgusunu biçimlendiren özgün nitelikler arasında; kitle iletişim araçlarının yapısındaki ve işleyişindeki değişimler ile rekabetle üretilmiş ve popülist "haber değeri taşıma" kavramıyla bütünleşmiş "bulvar" (tabloid) basınının ortaya çıkış1 gösterilebilir (Dunning ve ark., 1989). Gerçekten günümüzde özellikle televizyonun etkisiyle, kitle kültürünün yerini popüler kültürün aldığı görülmektedir. Hatta fertler için bu kültür, yavaş yavaş dünyayı yeni baştan algılama biçimine dönüşmekte, yaş ve sınıf farkı gözetmemektedir (Yetim, 2000). Elbette kitle iletişim araçları bu sürece kendi başına yol açmamıştır. Fakat bir tür kendi gerçekleşmesini kendisi sağlayan kehanet gibi, medya tutumunun futbol fanatikliğinin bugünkü açlk seçik biçimine kavuşmasında önemli bir rol oynadığı söylenebilir (Dunning ve ark., 1989).

Bualandayapılan birçok araştırmada spor medyasıve şiddetilişkisi net bir şekildeortaya konulmuştur. Emniyet Genel Müdürlüğü tarafından sporda şiddetin önlenebilmesi amacı ile 2013 yılında, kulüp temsilcileri, kulüp güvenlik sorumluları, taraftar temsilcilikleri, spor medyası temsilcilikleri, gençlik hizmetleri ve spor il müdürlüğü görevlileri ile özel güvenlik teşkilatının görüşleri alınmış ve elde edilen veriler istatistiki olarak analiz ve senteze tabi tutulmuştur. Bu sonuçlara göre; sporda şiddete etki eden faktörlerin sırasıyla; taraftarın tutum davranışları $(\% 25,93)$, kulüp yöneticileri, sporcu ve teknik heyetin tutum ve davranışları $(\% 16)$ ve nihayet medya $(\% 12,43)$ olduğu tespit edilmiştir (Emniyet Gn.Md., 2013, s. 168). Değişik tarihlerde farklı kişi ve kurumlar tarafından sporda şiddetin kaynağını belirlemek amacıyla yapılan araştırmalarda ise sırasıyla; "seyircilere göre”, \% 68.6, \% 54.8, \%44.5, \%17.9 oranlarında, polise göre, \%34.9 oranında (Özsoy, 2012). TBMM tarafından yürütülen bir araştırmada da \%14 oranında sporda şiddetin sorumlusu olarak spor medyası gösterilmektedir. (TBMM Araştırma Komisyonu Raporu 2011). 
Diğer taraftan, seyirci davranışını etkileyebilecek etkenler genel manada sorgulandığında aşağıdaki gibi bir liste karşımıza çıkmaktadır (Acet, 2001, Güçlü ve ark, 2014, Köknel, 1996, Devlet Planlama Teşkilatı, 1990

- Seyirci kitlesinin büyüklüğü ve yoğunluğu,

- Seyircilerin durduğu yer ve maçı izleme şekli (oturarak ve ayakta),

- Beraber söylenen tezahüratlar (şarkı, marş ve türküler) ve sesin şiddeti,

- Seyircinin duygu durumu (acı, can sıkıntısı, kaygı-endişe, korku, kızgınlık, aşırı sinir duyarlılığı, kin, nefret ve düşmanlık),

· Spor kültürü ve kuralları hakkında yeterince bilgi sahibi olunmaması,

- Medyanın seyircileri tahrik edici haberler vererek olumsuz etkilemesi,

- Amigoların, federasyon ve kulüplerin seyirciyi olumsuz etkilemesi,

- Aşırı rekabet hissinin baskısının olması,

- Hakemlerin istenmeyen kararları,

- Sporcuların kavga etmesi,

- Yenilgi ve başarının önemi”

Aslında "Sosyal Öğrenme” teorilerine göre saldırganlık yahut şiddet, öğrenilen bir davranıştır ve saldırgan örnekleri gözlemek bireydeki durdurucu, frenleyici mekanizmayı bozar. Bu teorilere göre sahadaki şiddet hareketi, seyircide daha da büyük saldırganlık oluşturur (Özbaydar, 1983). Bu olayları abartılı bir şekilde medyada yayınlamak ise kitlelerin şiddet duygularını tahrik edebilir.

Saldırgan davranışların öğrenilmesinde iki temel kaynak, aile ve kitle iletişim araçlarıdır. Çocukların ilk ve en önemli modeli, aile büyükleridir. Bu kişilerin saldırganlık da dahil olmak üzere her türlü davranışları çocukları tarafından taklit edilir. Yaş ilerledikçe sosyal çevre genişler. Bunun en uç noktasında bütün dünyayı evimize getiren kitle iletişim araçları yer alır. Bir futbolcunun yaptığ 1 faulü hakemin görmemesi, bu sporcuyu, aynı davranışı tekrar etmesi konusunda cesaretlendirir. $\mathrm{Bu}$ maçın televizyondan yayınlanması durumunda ise, hakeme fark ettirmeden faul yapma şeklinde saldırgan davranışın çok daha geniş bir kesim tarafından taklit edilmesi ihtimali doğar (İkizler, 1994).

Yukarıda ifade edilen bilgiler doğrultusunda araştırmamızın amacı; yazılı ve görsel medyada yer alan haber ve programların bireysel şiddet açısından etkilerini belirlemek, kişilerin saldırganlık veya fair-play’e yönelmelerinde etkili olabileceği düşünülen gazete haberleri ve televizyon programlarının analizini yapmak ve çözüm önerileri sunmaktır.

\section{MATERYAL VE METOT}

Bu çalışmada betimleyici araştırma metodu kullanılmıştır. Araştırmanın evrenini, Türkiyede yaşayan tüm halk, örneklemini ise; altı coğrafi bölgede yer alan (Güneydoğu Anadolu bölgesine 
gönderilen anketlerden yanıt alınamadığı için çalışmaya dahil edilememiştir); Ankara, Erzurum, Giresun, Hatay, İstanbul, Muğla, Samsun ve Sinop illerinde ikamet eden, 687’si erkek, 483'ü kadın olmak üzere tesadüfi olarak seçilmiş toplam 1250 kişi oluşturmaktadır. Ancak hatalı ve cevaplanmayıp boş bırakılan 80 anket çıkarılarak toplam 1170 anket değerlendirmeye alınmıştır.

Çalışmadan veri toplamak amacıyla uzman görüşü alınarak araştırmacılar tarafından, bir anket hazırlanmıştır. Ön uygulama anketi, araştırma kapsamına yer almayan 150 kişiye uygulanmış ve böylece veri toplama anketinin geçerlik ve güvenirlik çalışması gerçekleştirilmiştir. Ön uygulama anketinde yer alan ve madde toplam korelasyonu 30'un altında kalan bir madde anketten çıkartılmıştır. Çıkartılan maddeden sonra kalan 14 madde ile asıl uygulama anketine son şekli verilmiştir. Anketin güvenirlik katsayısı cronbach alpha .80 olarak hesaplanmıştır.

Verilerin değerlendirilmesinde SPSS istatistik programından (SPSS 16 v.) yararlanılmıştır. Bu kapsamda elde edilen verilerin frekans, yüzde ve Ki-Kare dağılım ve analizleri hesaplanmış ve sonra örneklemde yer alan bireylerin yaş, cinsiyet, meslek ve eğitim özellikleri yönünden değerlendirilmesi yapılmıştır.

\section{BULGULAR}

Çalışmanın bulguları "medyada spor programlarını takip", "medyada yayınlanan spor programlarının sportif eğitim açısından yeterliliği", "televizyon spor programlarının şiddeti arttırıcı etkisi", "katılımcıların spor medya yazarları hakkındaki düşünceleri”, "spor medyasının bireyler üzerinde oluşturduğu etkiler" ve "katılımcılara göre medyada öncelikli yayınlanması istenen program türleri” başlıkları altında toplam altı tablo halinde sunulmuştur.

Tablo I: Medyadaki Spor Programlarını Takip Etme Oranı

\begin{tabular}{|c|c|c|c|c|c|c|c|c|c|c|c|c|c|c|c|}
\hline \multirow{3}{*}{\multicolumn{2}{|c|}{ DEĞİŞKENLER }} & \multicolumn{14}{|c|}{ SEÇENEKLER } \\
\hline & & \multicolumn{7}{|c|}{ Televizyon } & \multicolumn{7}{|c|}{ Gazete } \\
\hline & & Sik & $\%$ & Arada & $\%$ & Hiç & $\%$ & $P$ & Sik & $\%$ & Arada & $\%$ & Hiç & $\%$ & $P$ \\
\hline \multirow{4}{*}{ Yaş } & $13-20$ & 165 & 14.1 & 259 & 22.1 & 48 & 4.1 & \multirow{4}{*}{.035} & 122 & 10.4 & 254 & 21.7 & 96 & 8.2 & \multirow{4}{*}{.010} \\
\hline & $21-30$ & 194 & 16.6 & 223 & 19.1 & 47 & 4.0 & & 144 & 12.3 & 238 & 20.3 & 82 & 7.0 & \\
\hline & $31-40$ & 38 & 3.2 & 51 & 4.4 & 14 & 1.2 & & 32 & 2.7 & 41 & 3.5 & 30 & 2.6 & \\
\hline & $41-50$ & 58 & 5.0 & 52 & 4.4 & 21 & 1.8 & & 50 & 4.3 & 55 & 4.7 & 26 & 2.2 & \\
\hline \multirow{2}{*}{ Cinsiyet } & Erkek & 377 & 32.2 & 273 & 23.3 & 37 & 3.2 & \multirow{2}{*}{$<.001$} & 282 & 24.1 & 337 & 28.8 & 68 & 5.8 & \multirow{2}{*}{$<.001$} \\
\hline & Kadın & 78 & 6.7 & 312 & 26.7 & 93 & 7.9 & & 66 & 5.6 & 251 & 21.5 & 166 & 14.2 & \\
\hline \multirow{3}{*}{ Meslek } & Serbest & 97 & 8.3 & 76 & 6.5 & 26 & 2.2 & \multirow{3}{*}{$<.001$} & 72 & 6.2 & 93 & 7.9 & 34 & 2.9 & \multirow{3}{*}{.003} \\
\hline & Kamu & 119 & 10.2 & 157 & 13.4 & 48 & 4.1 & & 98 & 8.4 & 143 & 12.2 & 83 & 7.1 & \\
\hline & Öğrenci & 239 & 20.4 & 352 & 30.1 & 56 & 4.8 & & 178 & 15.2 & 352 & 30.1 & 117 & 10.0 & \\
\hline \multirow{3}{*}{ Eğitim } & İlköğretim & 67 & 5.7 & 78 & 6.7 & 31 & 2.6 & \multirow{3}{*}{.009} & 47 & 4.0 & 78 & 6.7 & 51 & 4.4 & \multirow{3}{*}{.012} \\
\hline & Lise & 228 & 19.5 & 319 & 27.3 & 69 & 5.9 & & 176 & 15.0 & 326 & 27.9 & 114 & 9.7 & \\
\hline & Üniversite & 160 & 13.7 & 188 & 16.1 & 30 & 2.6 & & 125 & 10.7 & 184 & 15.7 & 69 & 5.9 & \\
\hline
\end{tabular}


Görsel ve yazılı medyadaki spor programlarını izleme, cinsiyet ve meslek gruplarında anlamlı bulunmuştur $(\mathrm{p}<0,005)$ (Tablo 1). Buna göre, erkeklerin önemli çoğunluğu hem televizyon spor programlarını $(\% 32,2)$, hem de gazetelerin spor sayfalarını $(\% 28,8)$ çok sık izlemektedir. Bu oranların kadınlardaki görünümü ise hayli düşüktür (TV: \%6,7, Gazete: \%5,6). Diğer yandan meslek gruplarında; gerek televizyonu, gerekse gazeteleri, çok sık takip etme, en yüksek değere, öğrenci gruplarında ulaşmaktadır (TV: \%20,4, Gazete: \%15,2).

Tablo 2: Medya Spor Programlarının Sportif Eğitim Açısından Yeterliliği

\begin{tabular}{|c|c|c|c|c|c|c|c|c|c|c|c|c|c|c|c|}
\hline \multirow{3}{*}{\multicolumn{2}{|c|}{ DEĞİŞKENLER }} & \multicolumn{14}{|c|}{ SEÇENEKLER } \\
\hline & & \multicolumn{7}{|c|}{ Televizyon } & \multicolumn{7}{|c|}{ Gazete } \\
\hline & & Evet & $\%$ & Kismen & $\%$ & Hayır & $\%$ & $P$ & Evet & $\%$ & Kismen & $\%$ & Hayır & $\%$ & $P$ \\
\hline \multirow{4}{*}{ Yaş } & $13-20$ & 72 & 6.2 & 175 & 15.0 & 225 & 19.2 & \multirow{4}{*}{.023} & 58 & 5.0 & 157 & 13.4 & 256 & 22.0 & \multirow{4}{*}{.005} \\
\hline & $21-30$ & 56 & 4.8 & 143 & 12.2 & 265 & 22.7 & & 44 & 3.8 & 125 & 10.7 & 294 & 25.2 & \\
\hline & $31-40$ & 19 & 1.6 & 33 & 2.8 & 51 & 4.4 & & 12 & 1.0 & 36 & 3.1 & 55 & 4.7 & \\
\hline & $41-50$ & 11 & 0.9 & 53 & 4.5 & 66 & 5.6 & & 11 & 0.9 & 57 & 4.9 & 62 & 5.3 & \\
\hline \multirow{2}{*}{ Cinsiyet } & Erkek & 96 & 8.2 & 241 & 20.6 & 349 & 29.9 & \multirow{2}{*}{.673} & 81 & 6.9 & 224 & 19.2 & 381 & 32.6 & \multirow{2}{*}{.242} \\
\hline & Kadın & 62 & 5.3 & 163 & 13.9 & 258 & 22.1 & & 44 & 3.8 & 151 & 12.9 & 286 & 24.6 & \\
\hline \multirow{3}{*}{ Meslek } & Serbest & 27 & 2.3 & 67 & 5.7 & 104 & 8.9 & \multirow{3}{*}{.960} & 25 & 2.1 & 64 & 5.5 & 109 & 9.3 & \multirow{3}{*}{.633} \\
\hline & Kamu & 41 & 3.5 & 110 & 9.4 & 173 & 14.8 & & 27 & 2.3 & 111 & 9.5 & 186 & 15.9 & \\
\hline & Öğrenci & 90 & 7.7 & 227 & 19.4 & 330 & 28.2 & & 73 & 6.3 & 200 & 17.1 & 372 & 31.9 & \\
\hline \multirow{3}{*}{ Eğitim } & İlköğretim & 39 & 3.3 & 71 & 6.1 & 65 & 5.6 & \multirow{3}{*}{$<.001$} & 32 & 2.7 & 68 & 5.8 & 75 & 6.4 & \multirow{3}{*}{$<.001$} \\
\hline & Lise & 80 & 6.8 & 212 & 18.1 & 324 & 27.7 & & 65 & 5.6 & 197 & 16.9 & 353 & 30.2 & \\
\hline & Üniversite & 39 & 3.3 & 121 & 10.4 & 218 & 18.6 & & 28 & 2.4 & 110 & 9.4 & 240 & 20.5 & \\
\hline
\end{tabular}

Görsel ve yazılı basının sunduğu spor programlarının, "sportif eğitim açısından yeterliliği" ile katılımcıların eğitim durumu arasında yüksek düzeyde anlamlı değişim gözlenmiştir $(\mathrm{p}<0.05)$ (Tablo 2). Medyanın halka arz ettiği programlar, spor eğitimi yönünden, bütün eğitim kademelerince yetersiz görülmektedir. Özellikle bu oran, lise (TV: \%27,7, Gazete: \%30,2) ve üniversite mezunlarında önemli seviyededir (TV: \%18,6, Gazete: \%20,5). Bulgular ilköğretim, lise ve üniversite mezunları olarak beraberce değerlendirildiğinde; yayınları sportif eğitim açısından yeterli bulanlar (TV: \%13,4, Gazete: \%10,7) ile kısmen yeterli ve yetersiz bulanlar (TV: \%86,5, Gazete: \%89,2) arasında oldukça büyük fark vardır. Katılımcıların eğitim durumlarına göre ortaya çıkan görünüm, diğer değişkenler (yaş cinsiyet ve meslek) bakımından da farklı değildir. 
Tablo 3: Televizyonlardaki Spor Programlarının Şiddeti Arttırıcı Etkisi

\begin{tabular}{|c|c|c|c|c|c|c|c|c|c|c|}
\hline \multirow{3}{*}{\multicolumn{2}{|c|}{ Değișkenler }} & \multicolumn{9}{|c|}{ Seçenekler } \\
\hline & & \multicolumn{2}{|c|}{ Evet } & \multicolumn{2}{|c|}{ Bazı Programlar } & \multicolumn{2}{|c|}{\begin{tabular}{|l|} 
Bazı \\
Konuşmacılar
\end{tabular}} & \multicolumn{2}{|c|}{ Hayır } & \multirow[t]{2}{*}{$P$} \\
\hline & & $F$ & \multirow{2}{*}{\begin{tabular}{|l|}
$\%$ \\
7.1 \\
\end{tabular}} & \multirow{2}{*}{\begin{tabular}{|l|}
$F$ \\
192
\end{tabular}} & & \multirow{2}{*}{\begin{tabular}{|l|}
$F$ \\
87 \\
\end{tabular}} & \multirow{2}{*}{\begin{tabular}{|l|}
$\%$ \\
7.4 \\
\end{tabular}} & \multirow{2}{*}{\begin{tabular}{|l|}
$\mathbf{F}$ \\
110 \\
\end{tabular}} & \multirow{2}{*}{\begin{tabular}{|l|}
$\%$ \\
9.4
\end{tabular}} & \\
\hline \multirow{4}{*}{ Yaş } & $13-20$ & 83 & & & & & & & & \multirow{4}{*}{$<.001$} \\
\hline & $21-30$ & 94 & 8.0 & 176 & 15.0 & 98 & 8.4 & 96 & 8.2 & \\
\hline & $31-40$ & 38 & 3.2 & 30 & 2.6 & 21 & 1.8 & 14 & 1.2 & \\
\hline & $41-50$ & 31 & 2.7 & 34 & 2.9 & 45 & 3.8 & 21 & 1.8 & \\
\hline \multirow{2}{*}{ Cinsiyet } & \begin{tabular}{|l|} 
Erkek \\
\end{tabular} & 147 & 12.6 & 245 & 20.9 & 143 & 12.2 & 152 & 13.0 & \multirow{2}{*}{.388} \\
\hline & \begin{tabular}{|l|} 
Kadın \\
\end{tabular} & 99 & 8.5 & 187 & 16.0 & 108 & 9.2 & 89 & 7.6 & \\
\hline \multirow{3}{*}{ Meslek } & Serbest & 48 & 4.1 & 59 & 5.0 & 48 & 4.1 & 44 & 3.8 & \multirow{3}{*}{.002} \\
\hline & Kamu & 79 & 6.8 & 109 & 9.3 & 83 & 7.1 & 53 & 4.5 & \\
\hline & Öğrenci & 119 & 10.2 & 264 & 22.6 & 120 & 10.3 & 144 & 12.3 & \\
\hline \multirow{3}{*}{ Eğitim } & İlköğretim & 44 & 3.8 & 58 & 5.0 & 35 & 3.0 & 39 & 3.3 & \multirow{3}{*}{.319} \\
\hline & Lise & 126 & 10.8 & 223 & 19.1 & 130 & 11.1 & 137 & 11.7 & \\
\hline & Üniversite & 76 & 6.5 & 151 & 12.9 & 86 & 7.4 & 65 & 5.6 & \\
\hline
\end{tabular}

Televizyon spor programlarının şiddeti arttırıcı etkisi ile yaş ve meslek grupları arasında yüksek düzeyde anlamlı bir ilişki tespit edilmiştir ( $\mathrm{p}<0,005)$. (Tablo3)

Televizyonlardaki bazı konuşmacı ve spor programlarının şiddeti arttırıcı etkisine özellikle 13-20 (\%16,4), 21-30 (\%15) yaş grupları ve öğrenciler inanmaktadır.

Tablo 4: Katılımcıların Spor Medyasındaki Yazarlar Hakkındaki Düşünceleri

\begin{tabular}{|c|c|c|c|c|c|c|c|c|c|c|c|c|c|c|}
\hline \multirow{3}{*}{\multicolumn{2}{|c|}{ Değişkenler }} & \multicolumn{13}{|c|}{ Seçenekler } \\
\hline & & \multicolumn{2}{|c|}{ Çok Yararlı } & \multicolumn{2}{|c|}{$\begin{array}{l}\text { Tahrik } \\
\text { Edici }\end{array}$} & \multicolumn{2}{|c|}{ Yanlı } & \multicolumn{2}{|c|}{$\begin{array}{l}\text { Tansiyon } \\
\text { Arttırıc1 }\end{array}$} & \multicolumn{2}{|c|}{ Çok Bilgili } & \multicolumn{2}{|c|}{ Eğitimsiz } & \multirow[t]{2}{*}{$P$} \\
\hline & & F & $\%$ & F & $\%$ & $F$ & $\%$ & F & $\%$ & $\mathrm{~F}$ & $\%$ & $\mathrm{~F}$ & $\%$ & \\
\hline \multirow{4}{*}{ Yaş } & $13-20$ & 48 & 4.1 & 65 & 5.6 & 192 & 16.4 & 94 & 8.0 & 21 & 1.8 & 52 & 4.4 & \multirow{4}{*}{.005} \\
\hline & $21-30$ & 23 & 2.0 & 70 & 6.0 & 203 & 17.4 & 95 & 8.1 & 6 & 0.5 & 67 & 5.7 & \\
\hline & $31-40$ & 7 & 0.6 & 24 & 2.1 & 38 & 3.2 & 13 & 1.1 & 2 & 0.2 & 19 & 1.6 & \\
\hline & $41-50$ & 12 & 1.1 & 16 & 1.3 & 60 & 5.1 & 25 & 2.1 & 3 & 0.3 & 15 & 1.2 & \\
\hline \multirow{2}{*}{ Cinsiyet } & Erkek & 59 & 5.0 & 99 & 8.5 & 308 & 26.3 & 115 & 9.8 & 16 & 1.4 & 90 & 7.7 & \multirow{2}{*}{.034} \\
\hline & Kadın & 31 & 2.6 & 76 & 6.5 & 185 & 15.8 & 112 & 9.6 & 16 & 1.4 & 63 & 5.4 & \\
\hline \multirow{3}{*}{ Meslek } & Serbest & 17 & 1.5 & 32 & 2.7 & 81 & 6.9 & 38 & 3.2 & 6 & 0.5 & 25 & 2.1 & \multirow{3}{*}{.500} \\
\hline & Kamu & 20 & 1.7 & 57 & 4.9 & 139 & 11.9 & 55 & 4.7 & 5 & 0.4 & 48 & 4.1 & \\
\hline & Öğrenci & 53 & 4.5 & 86 & 7.4 & 273 & 23.3 & 134 & 11.5 & 21 & 1.8 & 80 & 6.8 & \\
\hline \multirow{3}{*}{ Eğitim } & İlköğretim & 23 & 2.0 & 29 & 2.5 & 60 & 5.1 & 36 & 3.1 & 7 & 0.6 & 21 & 1.8 & \multirow{3}{*}{.002} \\
\hline & Lise & 53 & 4.5 & 91 & 7.8 & 264 & 22.6 & 112 & 9.6 & 21 & 1.8 & 75 & 6.4 & \\
\hline & Üniversite & 14 & 1.2 & 55 & 4.7 & 169 & 14.4 & 79 & 6.8 & 4 & 0.3 & 57 & 4.9 & \\
\hline
\end{tabular}


Örneklemin spor yazarları ile ilgili düşüncesi, yaş ve eğitim gruplarında anlamlı bulunmuştur $(\mathrm{p}<0,005)$ (Tablo 4). Spor yazarlarını yanlı görenler yaşa göre; 13-20 (\%6,4) ve 21-30 yaş gruplarında $(\% 17,4)$, eğitim durumuna göre de; lise $(\% 22,6)$ e üniversite mezunu $(\% 11,9)$ gruplarında en yüksek orana ulaşmaktadır. Bu oransal farklılık yazarların "tahrik edici" ve "tansiyon artırıcı" görülme seçeneklerinde de belirgindir. Konu bütün değişkenler açısından ele alındığında, spor yazarlarını "olumlu" bulanlarla "olumsuz" bulanlar arasında oransal manada büyük farklar vardır. Mesela erkek ve kadınlarda bu oran; erkek için \%6,4 olumlu, \%52,3 olumsuz, kadınlarda \%4 olumlu, \%377,3 olumsuz şeklindedir.

Tablo 5: Spor Medyasının Bireyler Üzerinde oluşturduğu Etkiler

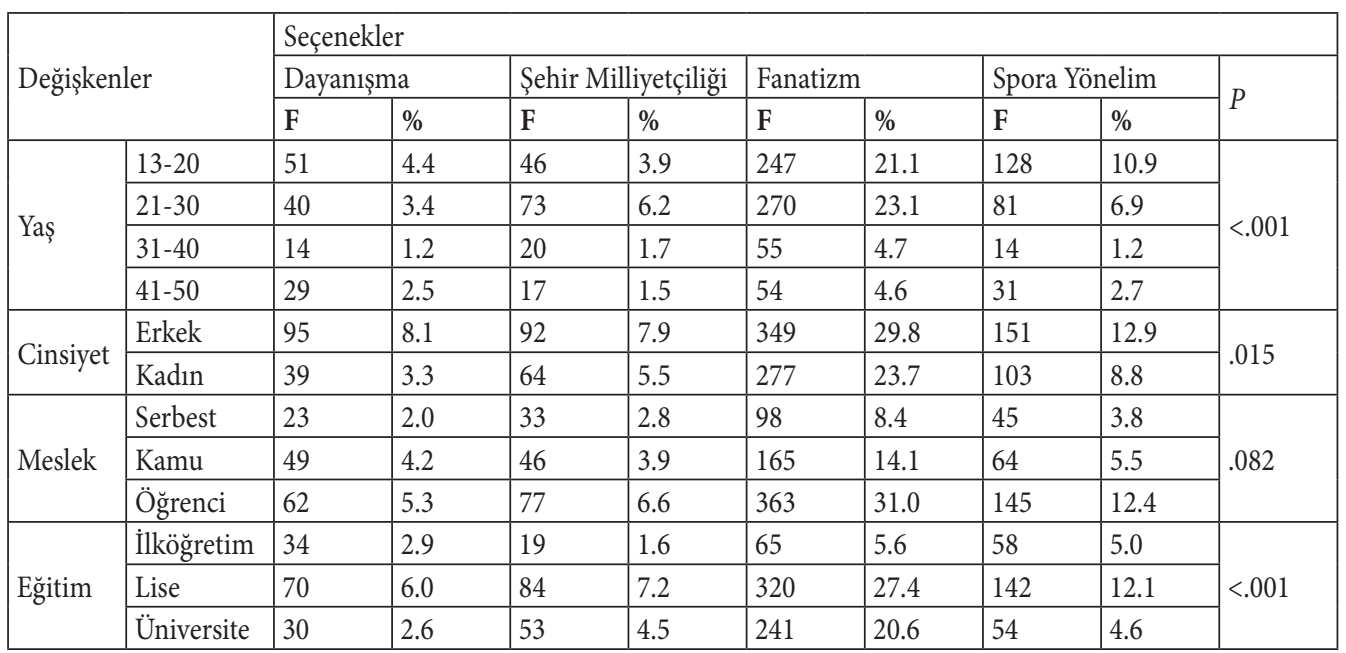

Spor medyasının bireyler üzerindeki etkisi, verilen seçeneklere göre sadece yaş ve eğitim durumu değişkenlerinde anlamlıdır ( $\mathrm{p}<0,005)$ (Tablo 5). Katılımcılara göre bu etki, hem yaş (13-20; \%21,1, 21-30; \%23,1), hem de eğitim gruplarında (lise; 27,4, Üniversite; \%20,6) öncelikle "fanatizm, sonra da "spora yönelim" olarak nitelendirilmektedir. Anlamlılık gösteren bu iki grupta fanatizmden sonra ikinci olan, medyanın halkı spora yönlendirdiği seçeneğidir. Fakat bu iki seçenek arasındaki fark hayli fazladır. Bununla birlikte, söz konusu etki, bütün bireylere göre ele alındığında; \%53,5 “fanatizm”, \%21,7 "spora yönelim”, \%13,4 "şehir milliyetçiliği”, \%11,4 "dayanışma” şeklinde ortaya çıkmaktadır. 
Tablo 6.I: Katılımcılara Göre Medyada Öncelikli Yayınlanması İstenen Program Türleri

\begin{tabular}{|c|c|c|c|c|c|c|c|c|c|c|c|c|c|c|c|c|c|}
\hline \multirow{2}{*}{\multicolumn{2}{|c|}{ Değiş̧kenler }} & \multicolumn{4}{|c|}{$\begin{array}{l}\text { Sportif Bilgiyi } \\
\text { Arttırıc1 }\end{array}$} & \multicolumn{4}{|c|}{$\begin{array}{l}\text { Spora Katılımı } \\
\text { Özendirici }\end{array}$} & \multicolumn{4}{|c|}{$\begin{array}{l}\text { Topla Oynanan Spor } \\
\text { Müsabakaları }\end{array}$} & \multicolumn{4}{|c|}{$\begin{array}{l}\text { Bireysel Spor } \\
\text { Müsabakaları }\end{array}$} \\
\hline & & $\mathrm{T}$ & $F$ & $\%$ & $P$ & $\mathrm{~T}$ & $\mathbf{F}$ & $\%$ & $P$ & $\mathrm{~T}$ & $F$ & $\%$ & $P$ & $\mathrm{~T}$ & $\mathrm{~F}$ & $\%$ & $P$ \\
\hline \multirow{4}{*}{ Yaş } & $13-20$ & 1 & 144 & 13.6 & \multirow{4}{*}{$<.001$} & 3 & 86 & 8.1 & \multirow{4}{*}{.059} & 6 & 92 & 8.9 & \multirow{4}{*}{.002} & 5 & 91 & 8.9 & \multirow{4}{*}{.037} \\
\hline & $21-30$ & 1 & 120 & 11.3 & & 2 & 111 & 10.4 & & 5 & 105 & 10.1 & & 6 & 134 & 13.1 & \\
\hline & $31-40$ & 3 & 26 & 2.5 & & 2 & 20 & 1.9 & & 5 & 33 & 3.2 & & 6 & 27 & 2.6 & \\
\hline & $41-50$ & 4 & 27 & 2.5 & & 1 & 26 & 2.4 & & 6 & 24 & 2.3 & & 6 & 31 & 3.0 & \\
\hline \multirow{2}{*}{ Cinsiyet } & Erkek & 1 & 191 & 18.0 & \multirow{2}{*}{.547} & 2 & 144 & 13.5 & \multirow{2}{*}{.107} & 5 & 133 & 12.8 & \multirow{2}{*}{$<.001$} & 6 & 164 & 16.0 & \multirow{2}{*}{.017} \\
\hline & Kadın & 1 & 110 & 10.4 & & 3 & 101 & 9.5 & & 5 & 110 & 10.6 & & 5 & 111 & 10.8 & \\
\hline \multirow{3}{*}{ Meslek } & Serbest & 1 & 49 & 4.6 & \multirow{3}{*}{.002} & 2 & 40 & 3.7 & \multirow{3}{*}{.449} & 6 & 34 & 3.3 & \multirow{3}{*}{$<.001$} & 6 & 46 & 4.5 & \multirow{3}{*}{.169} \\
\hline & Kamu & 4 & 61 & 5.7 & & 2 & 69 & 6.5 & & 5 & 85 & 8.2 & & 6 & 85 & 8.3 & \\
\hline & Öğrenci & 1 & 194 & 18.3 & & 2 & 128 & 12.0 & & 5 & 128 & 12.3 & & 6 & 143 & 14.0 & \\
\hline \multirow{3}{*}{ Eğitim } & İlköğretim & 1 & 37 & 3.5 & \multirow{3}{*}{.571} & 3 & 36 & 3.4 & \multirow{3}{*}{$<.001$} & 5 & 34 & 3.3 & \multirow{3}{*}{.633} & 6 & 39 & 3.8 & \multirow{3}{*}{.096 } \\
\hline & Lise & 1 & 172 & 16.2 & & 2 & 122 & 11.4 & & 5 & 123 & 11.8 & & 6 & 131 & 12.8 & \\
\hline & Üniversite & 1 & 92 & 8.7 & & 1 & 88 & 8.2 & & 5 & 86 & 8.3 & & 6 & 104 & 10.2 & \\
\hline
\end{tabular}

T:tercih sırası, F: kişi sayısı, $P$ : Anlamlılık değeri

Tablo 6.2: Katılımcılara Göre Medyada Öncelikli Yayınlanması İstenen Program Türleri

\begin{tabular}{|c|c|c|c|c|c|c|c|c|c|c|c|c|c|}
\hline \multirow{2}{*}{\multicolumn{2}{|c|}{ Değişkenler }} & \multicolumn{4}{|c|}{$\begin{array}{l}\text { Çocuk Spor - Eğitim } \\
\text { Programları }\end{array}$} & \multicolumn{4}{|c|}{$\begin{array}{l}\text { Sağlık İçin Spor } \\
\text { Programları }\end{array}$} & \multicolumn{4}{|c|}{$\begin{array}{l}\text { Futbolla İlgili } \\
\text { Yayınlar }\end{array}$} \\
\hline & & $\mathrm{T}$ & F & $\%$ & $P$ & $\mathrm{~T}$ & $F$ & $\%$ & $P$ & $\mathrm{~T}$ & $F$ & $\%$ & $P$ \\
\hline \multirow{4}{*}{ Yaş } & $13-20$ & 3 & 94 & 8.9 & \multirow{4}{*}{.044} & 1 & 81 & 7.6 & \multirow{4}{*}{.034} & 7 & 135 & 13.0 & \multirow{4}{*}{.024} \\
\hline & $21-30$ & 3 & 99 & 9.4 & & 2 & 84 & 7.9 & & 7 & 172 & 16.5 & \\
\hline & $31-40$ & 3 & 24 & 2.3 & & 1 & 30 & 2.8 & & 7 & 39 & 3.8 & \\
\hline & $41-50$ & 2 & 28 & 2.7 & & 1 & 27 & 2.5 & & 7 & 26 & 2.5 & \\
\hline \multirow{2}{*}{ Cinsiyet } & Erkek & 3 & 140 & 13.3 & \multirow{2}{*}{$<.001$} & 4 & 111 & 10.4 & \multirow{2}{*}{$<.001$} & 7 & 154 & 14.8 & \multirow{2}{*}{$<.001$} \\
\hline & Kadın & 2 & 110 & 10.5 & & 1 & 137 & 12.8 & & 7 & 218 & 21.0 & \\
\hline \multirow{3}{*}{ Meslek } & Serbest & 3 & 33 & 3.1 & \multirow{3}{*}{$<.001$} & 2 & 36 & 3.4 & \multirow{3}{*}{.027} & 1 & 57 & 4.9 & \multirow{3}{*}{$<.001$} \\
\hline & Kamu & 3 & 75 & 7.1 & & 1 & 73 & 6.8 & & 7 & 108 & 10.4 & \\
\hline & Öğrenci & 3 & 133 & 12.6 & & 3 & 112 & 10.5 & & 7 & 217 & 20.9 & \\
\hline \multirow{3}{*}{ Eğitim } & İlköğr. & 2 & 33 & 3.1 & \multirow{3}{*}{.351} & 1 & 39 & 3.6 & \multirow{3}{*}{0.774} & 7 & 44 & 4.2 & \multirow{3}{*}{.004} \\
\hline & Lise & 3 & 125 & 11.9 & & 1 & 107 & 10.0 & & 7 & 188 & 18.1 & \\
\hline & Ünivrst. & 3 & 91 & 8.7 & & 2 & 67 & 6.3 & & 7 & 140 & 13.5 & \\
\hline
\end{tabular}

T:tercih sırası, F: kişi sayısı, $P$ : Anlamllılk değeri

Ki-Kare dağılım testi sonucunda, medyada öncelikli yer alması istenen "sportif bilgiyi artırıcı" programlar ile yaş ve meslek grupları dağılımları arasında fark belirlenmiştir $(\mathrm{P}<0.05)$. Sportif bilgiyi geliştirmeye yönelik programlar bireylerinin genelde birinci sırada izlemek istediği 
yayınlar olarak dikkat çekmektedir. Aynı şekilde “spora katılımı özendirici” programlar ile eğitim durumu arasındaki tercih dağılımları da farklı bulunmuştur $(\mathrm{P}<0.05)$. Söz konusu seçenek bütün katılımcı grupları arasında ilk üç sırada tercih edilmektedir. Eğitim durumlarına göre bu tür programları medyada görmek isteyenler, birinci tercih ile üniversite mezunları $(\% 8,2)$, ikinci tercihle lise mezunları $(\% 11,4)$ ve nihayet üçüncü tercihle ilköğretim mezunları $(\% 3,4)$ biçiminde ortaya çıkmıştır.

Araştırmada "çocuklara yönelik spor programları" ile "cinsiyet" ve "meslek" grupları arasındaki tercih dağılımı da farklılık göstermektedir $(\mathrm{P}<0.05)$. Bu seçeneği kadınlar ikinci, sırada $(\% 10,5)$, erkekler ise, üçüncü sırada $(\% 13,3)$ tercih etmişlerdir. Meslek gruplarının tamamı bu tip programların 3. Sırada yer almasını istemektedir. Diğer yandan, cinsiyet grupları açısından tercih dağılımına bakıldığında; "sağlık için spor programları" ön plana çıkmakta ve anlamlı bir farklılık ortaya koymaktadır $(\mathrm{P}<0.05)$. Bu tür programları kadınlar ilk sırada $(\% 12,8)$, erkekler ise dördüncü sırada $(\% 10,4)$ tercih etmektedirler. Bunların yanı sıra futbolla ilgili yayınlar ile cinsiyet, meslek ve eğitim grupları arasındaki dağılım da anlamlı şekilde farklı bulunmuştur $(\mathrm{P}<0.05)$. Yani burada, yaş cinsiyet meslek ve eğitim grupları altında yer alan bütün kategorilerin (serbest meslek mensupları dışında) futbolla ilgili yayınları son sırada tercih ettikleri anlaşılmaktadır.

Araştırmada bireysel sporlarla ilgili yayınlar ile örneklemin tercih dağılımları arasında anlamlı bir farklılığa rastlanmamıştır $(\mathrm{P}>0.05)$. Bireylerin bu programları genelde 5. ve 6. sırada tercih ettikleri görülmektedir. Öte yandan, topla oynanan oyunlar seçeneği tercih dağılımda eğitim dışındaki diğer bütün değişkenlerde anlamlı farklılık bulunduğu halde tercihlerin 5 ve 6 . tercihlerde yoğunlaştı̆̆ belirlenmiştir.

\section{TARTIŞMA}

$\mathrm{Bu}$ çalışma yazılı ve görsel medyada yer alan program ve haberlerin bireyleri şiddete veya erdemli davranışlara yöneltme açısından ne denli tahrik edici veya yönlendirici olduğunu tespit etmek amacını taşımaktadır. Günümüz iletişim ve tanıtımının en güçlü enstrümanı kuşkusuz internet bağlantılı akıllı telefonların yanı sıra, kitle iletişim araçları olarak tanımlanan televizyon ve gazetelerdir. Gerçekten Türk ailesinin temel referans noktalarından biri haline gelen ve hemen her ailede (\%98) bulunan televizyon, fertlerin hayatına nüfuz etmekte (Batmaz ve ark., 1995), çok sayıda gazete ve dergi de günlük, haftalık veya aylık olarak halkın hizmetine sunulmaktadır. Tartışmasız bu görsel ve yazılı basın yoğun ve yaygın bir şekilde Türkiye ve dünyadaki spor olgu ve olaylarını gündeme getirmekte, böylece birey ve toplumu bilgilendirici bir hizmet yürütmektedir. Fakat bütün bu iletişim imkânlarına rağmen, Türk halkının spor programlarına yeterince ilgi gösterdiğini söylemek zordur. Bu araştırmada spor medyasındaki yayınları takip yaş büyüdükçe düşmekte, kadınların ilgisi ise erkelere göre daha alt düzeydedir. Eğitim kademelerinde ise en düşük izlenme oranı ilköğretim kademesi mezunlarında görülmektedir (Tablo 2). Oysa Amerikada spor programları izlenme oranı daha 1970'li yıllarda \%60 seviyesinden yüksek (14) ve muhtemelen toplumun her kademesini içine alan bir yaygınlık sergilemektedir. 
$\mathrm{Bu}$ araştırmaya katılan bireylerin genelinde, medyanın spor eğitimi konusunda üzerine düşen sorumluluğu yerine getirmediği kanaati hâkimdir. Dolayısıyla araştırmada yer alan bireyler sportif eğitim içerikli medya programlarının yetersizliği konusunda hemfikirdir (Tablo 2).

Günümüzde "medyada ağırlıklı yer alan spor programları eğitici-öğretici bir anlayış içinde olmayıp, tam anlamıyla fanatizmi ön plana çıkaran bir görüntü sergilemektedir. Ayrıca mevcut yayınların spor dalları arasında bir denge sağladığını söylemek imkânsızdır. Ne yazık ki geçmişte eleştirilen devlet kanallarının izlemiş olduğu spor yayın politikası dahi, bugün uygulanır değildir. Hatta bu konuda eski uygulamaların gerisinde kalındığı bile söylenebilir. (Taşmektepligil ve ark. 1999). Oysa gerek devlet gerekse özel devlet medya kuruluşlarının bireylerde şiddet algısı oluşturmayacak veya fanatik davranışı özendirmeyecek tarzda dikkatli programlara yer vermeleri ve bu noktada hassasiyet göstermeleri gerekmektedir.

Bugün resmen değil ama fiilen futbol sektörü ile medya arasında neredeyse bağımsız bir güç gibi dev bir çark vardır (Taşmektepligil ve ark. 1999). Elbette bu çark sportif eğitim ve etik kavram ve uygulamalarından çok ekonominin temel ilkeleri doğrultusunda işlemektedir. Dolayısıyla artık medyada "toplumu yönlendirmek ve bilgilendirmek anlayışı, yerini sansasyona dayalı haber üreten bir çarpık uygulamaya terk etmiş" bulunmaktadır (Horak R, ve ark., 1993).

$\mathrm{Bu}$ araştırma sonuçlarına göre özellikle televizyon spor programlarının daha çok genç, dinamik ve heyecanlı bireyler tarafından şiddete yöneltici bulunması hayli düşündürücüdür ve bu manada ciddi bir risk görülmektedir (Tablo 3). Esasen bu tehlike izleyicilerde "futbol fanatizmi” olarak yaftalanabilecek davranışları güçlendirmesi yönüyle değerlendirilmelidir. Örneğin, popüler kullanımda bu yafta, küfretmeyi sıradan "keyfilik" ya da "taşkınlık" olarak mazur görebilecek davranışlar içerir (Dunning ve ark., 1989). Hatta aktörler eylemlerinin bir meşruluk görüntüsüne sahip olduğuna güvenerek bir ölçüde iç rahatlığıyla, hırslarını fiziksel zarar yoluyla tatmin etme imkânına sahiptirler (Riches, 1989).

Bu çalışmada örneklemin spor yazarları ile ilgili düşüncesi, yaş ve eğitim gruplarında anlamlı diğer gruplarda ise anlamsız bulunmuştur. Gruplar arasında bir değişimin gözlenmediği seçeneklerde bile katılımcıların olumsuz düşünceleri hayli yüksek oranda ve birbirlerine yakındır. Ancak oransal farklılık bilhassa yazarların "tahrik edici" ve "tansiyon artırıcı" görülme seçeneklerinde de belirgindir. Konu bütün değişkenler açısından ele alındığında, spor yazarlarını "olumlu" bulanlarla "olumsuz" bulanlar arasında oransal manada büyük farklar vardır. Ayrıca yazarları çok bilgili görenlerin oranı hayli düşüktür (Tablo 4).

Maç analiz yapan yorumcular ile müsabakaları canlı yayınlarda sunan spikerlerin sadece izleyici kaybı endişesi ile yaptıkları seviyesiz, bilgiden uzak, taraflı yayın anlayış ve söylemleri bir taraftan fanatizmi körükleyebilirken diğer yandan doğruluk, dürüstlük gibi kültürel değerlerimizin de aşınmasına sebebiyet verebilmektedir (Taşmektepligil ve ark.,1999). Gerçekten üslup ve içerik yönünden pek çok program ve konuşmacının bu anlayışı pekiştirdiği söylenebilir. Kaldı ki bu görüşü bir araştırmaya göre, spor yazarları da desteklemektedir. Nitekim sözü edilen çalışmada, medyanın fanatizmi körüklediği konusuna 100 spor yazarından 36's1 "tamamen 27’si "oldukça" 
31'i "kısmen" katıllyorum demekte ve sadece 6 yazar bu görüşe "hiç katılmadı̆̆ını" ifade etmektedir (Döşyılmaz, 1988). Spor yazarı Uluç bu durumu, kısaca “ Bütün Türkiye özellikle şunu öğrenmelidir ki tribünlerdeki bütün çirkin görüntülerin baş sebebi yazılı ve görsel basındır” ifadesi ile açık bir şekilde belirtmektedir (Uluç, 1993).

Görülen o ki, Türk toplumu spor yazarlarını güvenilir bulmamaktadır. $\mathrm{Bu}$ sonucun ortaya çıkmasında yazarların gazetecilik kimliğinden sıyrılıp haber yapan bir taraftar gibi davranmalarının etkisi çoktur. Oysa yazarlar haber yapan birer taraftar olmayacakları gibi, dürüst ve doğru haber yapmaya da mecburdurlar (Catherine, 1990).

Esasen spor yazarı, bir başarının, gelişmenin, değişmenin, gerilemenin veya yenilginin nedenlerini objektif bir şekilde araştıran, gerçekleri ortaya çıkaran ve kendi yargısını ekleyip ifade eden kişidir (Acet, 2001). Fakat ne var ki, günümüzde çoğu medya mensubu, olaylara bir taraftar gibi duygusal plandan yaklaşmakta, kalemini, mikrofonunu, sayfasını ve ekranını bir amigo gibi kullanmaktadır (Erdem, 1997).

$\mathrm{Bu}$ araştırmada spor medyasının bireyler üzerindeki etkisi, verilen seçeneklere göre sadece yaş ve eğitim durumu değişkenlerinde anlamlı bulunmuştur. Burada özellikle fanatizm seçeneği 1330 yaşlar arasında, her iki cinsiyette, kamu çalışanları dışındaki meslek gruplarında ve son olarak lise ile üniversite mezunları gruplarında en yüksek frekansa ulaşmaktadır. Katılımcılar medya etkisini önce "fanatizm" (\%53,5), sonra da "spora yönelim" $(\% 21,7)$ olarak nitelendirilmektedir. Şehir milliyetçiliği ve dayanışma seçenekleri ise daha geri plandadır (Tablo 5).

Türkiyede "yazılı basın spor haberlerini aktarırken ağırlıklı olarak askeri terimler ve ifadeler kullanmaktadır. Özellikle derbi niteliğinde olan müsabakalarda bu tip terimlerin yoğunlaştığı, bu haftalarda gerek seyirci gerekse sporcu ve yöneticilerin saldırgan davranışlara daha fazla meyilli olduğu" (Küçük ve ark., 1998) görülmektedir. Ayrıca, şiddet olaylarının tekrar tekrar ve hatta biraz da sansasyonel bir şekilde abartılarak medyada yayınlanması kitlelerin şiddetle ilgili duygularını da tahrik edebilmektedir. Popüler basın artık maçlara sadece oyunun kendisi hakkında değil, kitle davranışları hakkında haber toplamak üzere muhabir göndermeye başlamıştır. Lakin muhabirlerin gördüğü olaylar her zaman gerçekleşebilecek türden olmasına rağmen haberin veriliş biçimi ile gerçekleşme şekli arasında önemli farklılıklar müşahede edilmektedir. Bu şekilde futbol fanatikliğinin haber veriliş oranı, gerçekleşmekte olan olgusal artışla orantısız bir şekilde şişirilmeye başlanmış, futbol sahaları artan ölçüde, sadece futbolun değil, dövüşlerin ve huzur bozucu olayların düzenli olarak sahnelendiği yerler olarak sunulur hale gelmiştir. Şüphesiz bu durum sözü edilen türden olayları tatmin edici ve heyecanlı bulan genç erkekleri şiddete itme açısından etkili olmaktadır (Dunning ve ark., 1989).

Fakat bütün bunlara rağmen bilinmelidir ki, bugün dünya üzerinden futbolu kaldırsanız veya sportif faaliyetleri tümden durdursanız da fanatizm başka bir sporda, başka bir oyunda kendini göstermekten geri kalmayacaktır. Belki briçte, hatta satrançta ortaya çıkacaktır. Çünkü beyinlerin ve yüreklerin kazanmaya ama mutlaka kazanmaya şartlandığı, asaletin ve nezaketin bunca estetik müdahale geçirdiği bir âlemde maalesef kaçınılmaz sonuç bu olacaktır (Bayhan, 2000). 
Aslında spor medyasının birey üzerine etkisi pek çok ülkede olumsuz algılanmaktadır. Nitekim Amerika'da yapılan bir araştırmada, halkın dört ana kitle iletişim aracı (TV, Radyo, Gazete, Dergi) arasından, en çok güvendiği birin seçmesi istendiğinde, her 10 kişiden 6'sı televizyonu seçmiştir. Fakat ne var ki televizyonu seçenler arasından sadece \%25'i televizyonu tam güvenilir bulmuştur. Diğer yandan, aynı araştırma bu oranın önceki yıllara göre oldukça düşük olduğunu da ortaya koymuştur (Özseyhan).

Çalışma bulgulardan anlaşılacağı gibi; katılımcılar, bilgi, eğitim, çocuk ve sağlık üzerine yapılacak program-yayınları ilk üç sırada görmek istemektedir (Tablo 6.1, Tablo 6.2). Spor müsabakaları ve futbolla ilgili yayınlar ise uygulamaların aksine halkın son siralamalarda görmek istediği programlardır. Oysa günümüzde halk çoğunlukla futbol yayını izlemektedir. Fakat bu durum eldeki çalışmaların bulgularıyla örtüşmemektedir. Burada televizyon ve gazetelerde futbol dışı yayınların yeterince yer almayışı yahut alternatif programların bulunmayışı halkı bu yönde bir tercihe zorlamış olabilir. Nitekim ANAR tarafından Türkiye’nin farklı bölgelerindeki 20 ilde 3500 kişi üzerinde yapılan çalışmada; izleyicilerin daha fazla gösterilmesini istedikleri programların başında eğitici, öğretici toplumu bilgilendirici yayınların geldiği ifade edilmektedir (ANAR Sosyal Araştırma Merkezi, 1999). Fakat ne yazık ki her kulüp bayrağının banknot olarak görüldüğü bu sistemde, eğitim programlarının diğer programlarının karşısında seyredilme şansı da yok denebilecek kadar azdır.

\section{SONUÇ VE ÖNERILER}

Bir eylem yolu olarak şiddet toplumlarda hoş görülmeyen bir durumdur ve kontrol edilmesi oldukça güçtür. Aslında toplumu pek çok sosyal rol kuşatmışken şiddet olgusunun gerçekliğini kavramak hayli zordur. Fakat bilinen o ki, normalde istenen hedeflere ulaşmanın başka araçları da vardır. Kişilerin bir çatışma içinde yer alsa bile, bu durum hiçbir şekilde rakibe fiili olarak zarar vermeyi gerektirmez. Böylesi bir atmosferin oluşturulması şüphesiz eğitim olgusu ile alakalıdır ve ondan bağımsız düşünülemez.

Günümüzde eğitimin en önemli araçlarından biri olarak medya gösterilmektedir. Çünkü kitle haberleşme araçları, Türkiye’de hemen her bireyin kolaca ulaşabileceği yaygın olarak kullanabileceği bir özellik taşımaktadır.

$\mathrm{Bu}$ araştırmada görsel ve yazılı medyadaki spor programlarını izleme, cinsiyet ve meslek gruplarında anlamlı bulunmuştur. Erkeklerin büyük çoğunluğu hem televizyon spor programlarını, hem de gazetelerin spor sayfalarını çok sık izlemektedir. Bu oranların kadınlardaki görünümü ise hayli düşüktür. Televizyon ve gazete çok sık takip etme, en yüksek değere öğrenci gruplarında ulaşmaktadır.

Görsel ve yazılı basının sunduğu spor programlarının, "sportif eğitim açısından yeterliliği ile katılımcıların eğitim durumu arasında anlamlılık vardır. Medyanın halka sunduğu programlar, spor eğitimi yönünden, bütün eğitim kademelerince yetersiz görülmektedir. Durum diğer 
değişkenler açısından da benzerdir. Yani bireyler çoğunlukla, medyanın spor eğitimindeki fonksiyonunun yetersizliğinden şikâyetçidir.

Televizyon spor programlarının şiddeti artırıcı etkisi ile yaş ve meslek grupları arasında anlamlılık tespit edilmiştir. Televizyonlardaki bazı konuşmacıların ve spor programlarının şiddeti artırıcı etkisine özellikle 13-30 yaş aralığındakilerle öğrenci bireyler inanmaktadırlar. Televizyon spor programlarının dinamik ve heyecanlı bireyler tarafından şiddete yöneltici bulunması hayli düşündürücüdür ve bu konuda mutlak tedbir alınmasını gerektirmektedir.

Diğer yandan katılımcıların spor yazarları ile ilgili düşüncesi, yaş ve eğitim gruplarında anlamlı bulunmuştur. Konu bütün değişkenler açısından ele alındığında, spor yazarlarını "olumlu" bulanlarla "olumsuz bulanlar arasında oransal manada büyük farklar vardır. Neticede, Türk toplumu spor yazarlarını pek güvenilir bulmamaktadır.

Spor medyasının bireyler üzerindeki etkisi, verilen seçeneklere göre, sadece yaş ve eğitim durumu değişkenlerinde anlamlıdır. Örnekleme göre bu etki, yaş ve eğitim gruplarında öncelikle "fanatizm", sonra da "spora yönelim olarak nitelendirilmektedir. Anlamlılık gösteren bu ili grupta fanatizmden sonra ikinci sırada medyanın halkı spora yönlendirdiği seçeneğidir. Fakat bu iki seçenek arasındaki fark hayli fazladır. Bununla birlikte, söz konusu etki, bütün katılımcılara göre ele alındığında sırasıyla; "fanatizm, "spora yönelim", "şehir milliyetçiliği” ve dayanışma" seçenekleri şeklinde ortaya çıkmaktadır.

Günümüzde özellikle televizyonun etkisiyle, kitle kültürünün yerini popüler kültür almıştır. Öyle ki zaman zaman spor haberinin veriliş üslubu ile gerçekleşme biçimi arasında önemli farklar görülmektedir. Şüphesiz bu durum fanatik davranışların benimsenmesinde etkili olmaktadır. Bu noktada spor olaylarının medyada abartısız verilmesi son derece önemlidir.

Bunun gibi "Spora katılımı özendirici programlar" seçeneğinde programlar ile eğitim durumu arasındaki dağılımda da anlamlılık bulunmuştur. Söz konusu seçenek bütün katılımcı gruplar arasında ilk üç sırada tercih edilmektedir. Benzer şekilde "çocuklara yönelik spor eğitim programları" ile cinsiyet ve meslek grupları arasındaki dağılım da anlamlı bulunmuştur. Bu seçeneği kadınlar ikinci, erkekler de, üçüncü sırada tercih etmiştir. Meslek grupları ise bu tip program yayınlarının 3. Sırada yer almasını istemektedir. Diğer yandan, sağlık için spor programları ile cinsiyet grupları arasında da dağılım anlamlı çıkmıştır. Erkekler bu programları dördüncü sırada isterken, kadınlar ilk sırada tercih etmektedir.

Bunların yanı sıra futbolla ilgili yayınlar ile cinsiyet, meslek ve eğitim grupları arasındaki ilişki de anlamlıdır. Ancak serbest meslek” dışında, grupların hepsi futbolla ilgili yayınların son sırada yer almasını istemektedirler. Kısaca halkımız, bilgi, eğitim ve sağlı program veya yayınlarını öncelikli izlemek beklentisi içindedirler. Fakat ne var ki uygulamalar bireylerin bu taleplerinin tam tersi istikamette davrandıklarını göstermektedir.

Bu araştırmada ortaya çıkan sonuçlara göre aşağıdaki öneriler getirilebilir; 
- Medya spor yayın politikalarını tekrar gözden getirerek halkın isteği doğrultusunda yayınlarında ağırlıklı olarak spor eğitimine dikkat etmelidir.

- Medyada habercilik açısından branş çeşitliliği arttırılmalıdır.

· Özellikle yazılı medya spor müsabakalarıyla ilgili bahis tahminlerine yer veren bülten kimliğinden arındırılmalıdır.

- Sportif olaylar yazılır veya yayınlanırken küçük grupların oluşturduğu taşkınlıklardan ziyade büyük grupların memnuniyetleri dile getirilmelidir. Çünkü şiddete yönelik olaylara medya ilgisiz kaldığı sürece bu tür davranışların da azalacağı söylenebilir.

- Şiddetle ilgili olarak yayınların devlete bağlı bir kurum tarafından kontrol edilmesi, bu olaylara karşı tedbir olarak düşünülebilir.

- Medya kuruluşlarının, sağlık ve eğitim konularında yayın yapmaları devletçe özendirilmeli ve bu anlamda gereken destek yapılmalıdır. Hatta bu tür programların her yayın kuruluşunda belirli dönemlerde zorunlu olarak yayınlanması sağlanmalıdır.

- Şiddet olaylarının önlenmesi konusunda çıkarılan 6222 sayılı yasa esnetilmeden uygulanmalıdır

\section{KAYNAKLAR}

Acet, M. (2001). Futbol Seyircisini Fanatik ve Saldırgan Olmaya Yönelten Sosyal Faktörler, M.Ü. Sosyal Bilimler Enstitüsü Yayımlanmamış Doktora Tezi, s.124

Anar Sosyal Araştırmalar Merkezi, Ankara, 1999.

Baltaş, A. ve Baltaş, Z., Başarılı ve Sağlıklı Olmak İçin Stres ve Başa çıkma Yolları, Remzi Kitabevi, 8, Basım, İstanbul 1990, s.278.

Batmaz, V. Ve Aksoy, A. (1995). Televizyon ve aile Başbakanlık Aile Araştırma Kurumu, http:// dorduncukuvvetmedya.com/arastirma/aile.html,1995.

Bayhan, B., (2000), Fanatizm. Gözlem Dergisi, Mayıs, s, 2.

Catherine, A., P. (1990). Sport and Fitness Career Strategies and Professionel. Sports Journalism Human Kinetics Books, Chapter:8, USA, s, 85.

Devlet Planlama Teşkilatı (1990). Türk Sporu Niçin Uluslararası Sporun Gerisinde Kalmıştır (Araştırma Modeli), (Birinci Basım). Ankara: Devlet Planlama Teşkilatı.

Dönmezler, S. (1984). Sosyoloji Genişletilmiş 9. Baskı, Savaş Yayınları, Ankara, s, 408.

Döşyılmaz, E. (1998). Medyanın Toplum Üzerine Etkileri M.Ü. Sağlık bilimleri enstitüsü, Beden Eğitimi ve Spor anabilim dalı, Yayınlanmamış doktora tezi, İstanbul,. s.26.

Dunning, E.Murphy, P. Ve Williams, J. (1989). Keyfiler, Açık Tribün Çeteleri ve Kavga Şirketleri: Futbol Fanatiği Davranışının Sosyolojik Bir Açıklamasına Doğru, Antropolojik Açıdan Şiddet, Çeviren, Dilek Hattatoğlu, Ayrıntı Yayınevi, Birinci Basım, ss, 203-223.

Emniyet Genel Müdürlüğü (2013) Sporda Şiddetin Önlenmesi Raporu, s. 168.

Erdem, S. (1997) Sporda sevgi ve fanatizm http://www.turkiye.net/serdem/sevgi.htm,.

Güçlï M, Arıkan Y, Şanlı, S, Mil H. İ. (2014). Sportif Organizasyonlarda Güvenlik Stratejileri. Güvenlik Sektöründe Temel Stratejiler. Ed: Harmancı F. M., Gözübenli M., Zengin C. Ankara: GÜSAM-Nobel Yayınevi, ISBN:978-605-133-960-3, s. 35-38 
Horak R, Reiter V, Bora T, Erdoğan N. (1993). Dur Tarih, Vur Türkiye, Futbol Kültürü, İletişim Yayınları, İstanbul.

İkizler, C. (1994). Sporda Başarının Psikolojisi, Genişletilmiş 2. Baskı, Alfa Basım Yayım dağıtım, İstanbul, s.78.

Karaküçük, S. Ve Yenel, F. (1999). Spor Köşe Yazarlarının Okuyucuya Yansıttığı Görüşlerin Bir Analizi” G. Ü Spor Bilimleri Dergisi, C.4, No:1, ss,55-62.

Köknel, Ö. (1996). Bireysel ve Toplumsal Şiddet. İstanbul: Altın Kitaplar Basımevi.

Küçük, V. Ark. (1998). Kitle İletişim Araçlarından Yazılı Basının Kullanmış Olduğu Üslubun Sporcu ve Seyirci Saldırganlığı Açısından Değerlendirilmesi”, Spor Bilimleri Kongresi, 5-7 Kasım, Ankara, , s. 127.

Marovelli, E., Scott A. G. M. (1987). Mass Media Influence On Female High School Athletes Identification With Professional Athletes. International Journal of Sport Psychology, vol.18, No:3, , ss, 231-236.

Özbaydar, S., İnsan Davranışlarının Sınırları ve Spor Psikolojisi, Altin Kitaplar Yayınevi, Ankara, 1983, s.241.

Özseyhan, N., TV ve Siyaset. 4. Boyut Dergisi, ss, 18-29.

Özsoy, S., (2012). Toplumda her yönüyle şiddet ve çözüm önerileri raporu, Diyarbakır, s. 5.

Öztürk, F. (1989). ve ark., Günlük gazetelerde sporun yer alışı. G. Ü. Spor Billimleri Dergisi, S:3, s,24-32.

Riches, D., (1990). Şiddet Olgusu” Antropolojik Açıdan Şiddet, Çeviren, Dilek Hattatoğlu, Ayrıntı Yayınevi, Birinci Basım, , ss, 11-13-18.

Taşmektepligil,Y. (1999). Kamuoyu oluşturmada Kitle iletiş̧im araçlarının yeri ve sporun gelişimindeki etkileri, M.Ü. Sağlık Bilimleri Enstitüsü Beden Eğitimi ve Spor Anabilim Dalı, Doktora programı seminer çalışması, 5, İstanbul.

Türkiye Futbol Federasyonu (2011). Ocak 2009 Çözüme Doğru Antalya toplantısı ve TBMM Araştırması Komisyonu Anketi, TBMM Raporu.

Yetim, A. (2000). Sosyoloji ve Spor, Topkar Matbaas1, Trabzon, Ankara, , ss.47-175-177

Taşmektepligil MY, Sivrikaya H, Kaldırımcı M, Tutkun E, Aybek S. (1999). Sportif Gelişme ve Yerel Medya İlişkisi Üzerine Bir Araştırma, Hacettepe Üniversitesi Spor Bilimleri ve Teknolojisi Yüksekokulu, Futbol Bilim ve Teknoloji Dergisi,; 6 (3): 17-21.

Taşmektepligil MY, Çankaya S, Tunç T. (2015). Futbol taraftarı fanatiklik ölçeği. Spor ve Performans Araştırmaları Dergisi,; 6(1): 41-49.

Uluç H. (1993). Olimpiyat Öylemi, Sabah Gazetesi, 6 Nisan 